\title{
Study of Physicochemical Parameters of Rainwater: A Case Study of Karachi, Pakistan
}

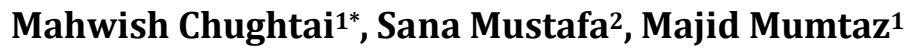 \\ ${ }^{1}$ Department of Chemistry, University of Karachi, Karachi, Pakistan \\ ${ }^{2}$ Department of Chemistry, Federal Urdu University of Arts, Science \& Technology, Gulshan-e-Iqbal Campus, \\ Karachi, Pakistan \\ Email: ${ }^{*}$ mahwishchughtai786@gmail.com
}

Received 16 January 2014; revised 21 February 2014; accepted 28 February 2014

Copyright (C) 2014 by authors and Scientific Research Publishing Inc.

This work is licensed under the Creative Commons Attribution International License (CC BY).

http://creativecommons.org/licenses/by/4.0/

\section{(c) (i) Open Access}

\section{Abstract}

The urban centers of developing countries like Karachi city in Pakistan are facing the menace of air pollution and atmospheric wet deposition can be used as a tool for monitoring the quality of air. In this study, rainwater samples from eighteen different towns of Karachi were collected during monsoon season (July to September, 2013) in triplicate and analyzed. Their pH (range 6.2 - 7.9), electrical conductivity (range $0.02-0.21 \mathrm{~m} \cdot \mathrm{S} / \mathrm{cm}$ ), total dissolved solids (range $32-159 \mathrm{mg} / \mathrm{l}$ ), dissolved oxygen (range $6.3-8.2 \mathrm{mg} / \mathrm{l})$ and hardness $(23-89 \mathrm{mg} / \mathrm{l})$ were immediately monitored within next twenty four hours of sample collections. The samples were then acidified and analyzed for the presence of major cations ammonium, sodium, potassium, magnesium and calcium by flame atomic absorption spectroscopy and flame emission spectroscopy. The anions fluoride, chloride, nitrate, carbonate and sulphate were analyzed by ion chromatography. The results of the analysis were compared with the values provided by WHO guidelines in order to access the quality of water. Most of the rainwater samples were completely free from considerable pollution and meet the WHO standard values. However, in Lyari, Gulshan, Shah Faisal, Landhi, Malir and Gadap town the concentration of $\mathrm{Mg}^{2+}$ and in North Nazimabad, Korangi, Gulshan, Saddar, Lyari, SITE and Keamari town the concentration of $\mathrm{NO}_{3}^{-}$is above the WHO standards, indicating their presence from air pollution.

\section{Keywords}

Rainwater; Air Pollution; Physicochemical Parameters; Karachi; Wet Atmosphere

\footnotetext{
"Corresponding author.
}

How to cite this paper: Chughtai, M., Mustafa, S. and Mumtaz, M. (2014) Study of Physicochemical Parameters of Rainwater: A Case Study of Karachi, Pakistan. American Journal of Analytical Chemistry, 5, 235-242. 


\section{Introduction}

Rain acts as a powerful mechanism to remove pollutants from the atmosphere. Precipitation chemistry is the result of a series of in-cloud and below-cloud atmospheric chemical reactions and a complex interaction between microphysical processes and cloud dynamics [1]. Rainwater composition is important in evaluating the role of transport of soluble material and the contribution of different sources of atmospheric pollutants.

Aerosols and gases released into the atmosphere can be transported over long distance from their sources, and can be removed by dry or wet deposition [2] [3]. Every day, large quantities of anthropogenic and natural material are dumped into the atmosphere and majority of this material returns to the ground. Man is primarily responsible for the enrichment of many trace elements in the atmosphere caused by the combustion of fossil fuels, including such additives as lead in gasoline, processing of crustal materials for manufacturing cements, roasting of ores for refining metals, and burning of waste materials [4]. Many industrial processes produce large quantities of oxides of sulfur and nitrogen is being emitted to the atmosphere, and these gases are being converted into strong acids, which lead to many areas experiencing precipitation of very low pH values [5]-[7]. Composition of rainwater varies from site to site and it is difficult to control as it is influenced by both natural and anthropogenic sources. If the source is influenced by man made activities more, it will contribute to acidic gases like $\mathrm{NO}_{\mathrm{x}}$ and $\mathrm{SO}_{\mathrm{x}}$ due to which rainwater becomes acidic and basic gases like $\mathrm{NH}_{3}$ [8] [9]. Environmental adverse effects of acid rain include changes in the leaching rates of nutrients from plant foliage and soil nutrients, acidification of lakes and rivers, effects on metabolism of organisms and corrosion of structures [10] [11]. In addition to that, acid rain is also responsible for reduction of visibility and deterioration of historical structures especially by damaging the details on historic places or sculptures [5] [12]. Precipitation composition thus is an indispensable measurement and helps to understand the comparative importance of the different sources of these materials.

Because of this concern, precipitation chemistry in both rural and urban areas has been the subject of intense research in the last two decades [13]-[16]. Currently, there are more than 1000 stations conducting precipitation chemistry measurements around the world. All these working stations may be categorized into global, regional and local networks. Global networks comprising the BAPMON (Background Air Pollution Monitoring Network) and GPCP (Global Precipitation Chemistry Project) sites collect precipitation at remote areas and provide worldwide information on the background concentration of air pollutants and long range transport of trace substances in the atmosphere. A large number of local networks are operated in several countries, which address specific scientific questions, abatement strategies and pollution issues. In various countries like Europe, North America regional networks are functioning and documenting spatial and long term trends in deposition of acidic materials [17].

Karachi is one of the largest mega cities of the world and most populous city of Pakistan, serving as the primary center of finance, commerce and industry. It is spread over approximately $3530 \mathrm{~km}^{2}(1362 \mathrm{sq} \cdot \mathrm{mi})$ in area [18]. The city population is growing at an alarming rate and results in the rapid increase of vehicle number ( $>1.3$ million) and energy consumption due to which air pollution situation has become severe in the city. The principal thrust of this study is to use the rainwater as a tool to examine the extent of air pollution and to compare the major physicochemical parameters to the WHO water standard guidelines. In the same series of research work a comprehensive article regarding the physicochemical assessment of rainwater of 2007 is recently published [19]. In the year 2009, 2010, 2011 and 2012 the precipitation events were very rare so no spatial sampling and analysis is done. Therefore, it is a second systematic report on the study of rainwater analysis of Karachi, Pakistan.

\section{Materials and Methods}

Rainwater samples were collected from different areas of Karachi city in the monsoon season of 2013, in clean polypropylene bowls. The bowls are placed $2 \mathrm{~m}$ above the ground level to avoid contamination from the ground. The rainwater samples were then transferred to the polypropylene bottles that were pre-rinsed with deionized water and properly caped to prevent the oxidation of the constituents. A total of fifty four samples from eighteen towns of Karachi were collected (Figure 1) and their pH, EC and DO were measured immediately. Each sample was filtered and divided into two portions. One part was stored at $4^{\circ} \mathrm{C}$ for anion analysis and other portion was acidified with $\mathrm{HNO}_{3}(\mathrm{BDH})$ for cation analysis. The major cations were measured by Perkin-Elmer atomic absorption spectrophotometer (AAnalyst 700). Anions were analyzed by ion chromatography (Metrohm 761 Compact IC with suppressed module, equipped with an anion-separator column (Dual 2). $\mathrm{pH}, \mathrm{EC}, \mathrm{DO}^{\mathrm{and}} \mathrm{NH}_{4}$ 


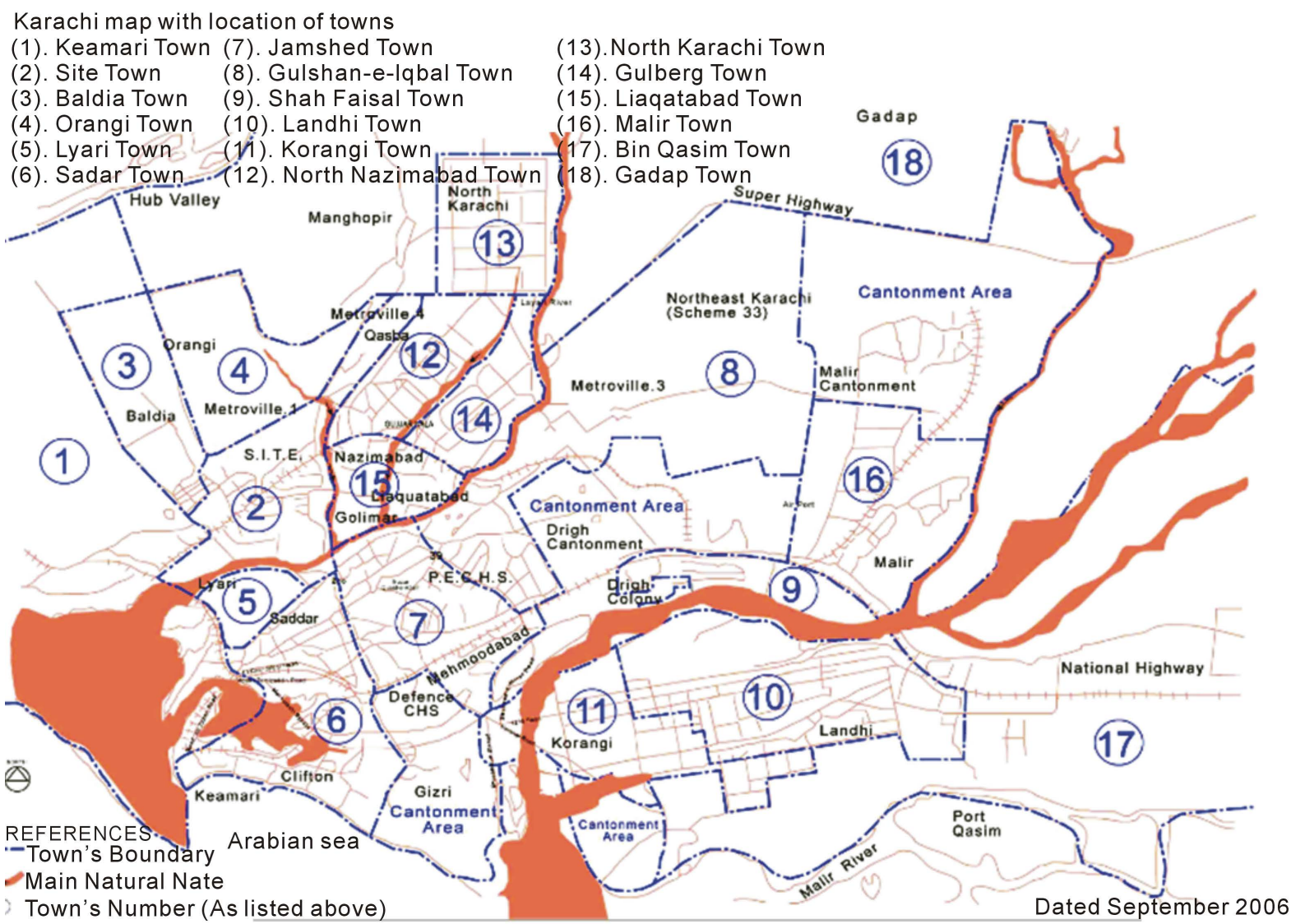

Figure 1. Geographical map of Karachi showing the location of sampling sites.

was analyzed by multiparameter ion analyzer (HANNA Instrument).

\section{Results and Discussion}

Atmosphere of Karachi is greatly influenced by the rapid urbanization which results in increased levels of atmospheric pollutants. Rainwater is an essential part of hydrological cycle that plays an important role in the global cycling of soluble chemicals in water. It serves as a cleanser of the atmosphere, washing out pollutants from air and introducing them into surface water and soil where it may have adverse effects on natural ecosystem. This study was aid to understand the effect of natural and anthropogenic effects on the quality of rainwater. In order to estimate the effect of pollution in air we analyzed rainwater samples collected from eighteen towns of Karachi, Pakistan, and results are summarized in Tables 1 and 2.

\subsection{Physical Parameters of Rainwater}

The results of the field measurements (pH and Total Dissolved Solids) and those obtained after analysis of the rainwater samples in the laboratory are shown in Figure 2.

\subsection{1. pH}

The acidity of rainwater depends on the concentration of anionic as well as cationic species. Acidic $\mathrm{pH}$ reveals the presence of strong acids while neutral or alkaline $\mathrm{pH}$ indicates neutralization of acids by carbonates, mineral dust or by ammonium. This may be due to the reaction of sulphuric and nitric acid absorbed in the aerosols with alkaline carbonates in the particulate matter [20]-[22]. pH is a useful tool for measuring the acidity of rainwater. The results demonstrated that no acid rain event is observed in Karachi as the recorded $\mathrm{pH}$ values of rainwater samples ranged from 6.2 - 7.9. The minimum $\mathrm{pH}$ was found in Saddar and Binqasim while highest concentration was found in Korangi industrial area. 
Table 1. Physical parameters (pH, EC, TDS, DO \& hardness \pm standard deviation) of rainwater samples at different sites of Karachi.

\begin{tabular}{|c|c|c|c|c|c|c|}
\hline S. No. & $\begin{array}{c}\text { Parameters/ } \\
\text { Sampling Site }\end{array}$ & $\mathrm{pH}$ & $\begin{array}{l}\text { Conductivity } \\
(\mathrm{m} \cdot \mathrm{S} / \mathrm{cm})\end{array}$ & $\begin{array}{l}\text { TDS } \\
(\mathrm{mg} / \mathrm{l})\end{array}$ & $\begin{array}{c}\mathrm{DO} \\
(\mathrm{mg} / \mathrm{l})\end{array}$ & $\begin{array}{c}\text { Hardness } \\
(\mathrm{mg} / \mathrm{l})\end{array}$ \\
\hline 1 & Keamari & $6.9 \pm 0.23$ & $0.12 \pm 0.01$ & $96.2 \pm 2.03$ & $7.2 \pm 0.08$ & $62 \pm 0.90$ \\
\hline 2 & SITE & $6.3 \pm 0.21$ & $0.15 \pm 0.03$ & $82.3 \pm 3.68$ & $6.9 \pm 0.09$ & $69 \pm 2.31$ \\
\hline 3 & Baldia & $6.5 \pm 0.19$ & $0.09 \pm 0.01$ & $72.0 \pm 6.23$ & $7.1 \pm 0.01$ & $60 \pm 3.21$ \\
\hline 4 & Orangi & $6.8 \pm 0.25$ & $0.13 \pm 0.03$ & $89.0 \pm 4.02$ & $6.9 \pm 1.02$ & $73 \pm 2.11$ \\
\hline 5 & Lyari & $6.9 \pm 0.17$ & $0.08 \pm 0.05$ & $125 \pm 5.99$ & $6.9 \pm 0.08$ & $70 \pm 0.98$ \\
\hline 6 & Saddar & $6.2 \pm 0.26$ & $0.09 \pm 0.02$ & $115 \pm 1.03$ & $7.3 \pm 0.05$ & $62 \pm 0.05$ \\
\hline 7 & Jamshed & $7.1 \pm 0.11$ & $0.16 \pm 0.01$ & $126 \pm 2.58$ & $6.9 \pm 0.11$ & $89 \pm 0.12$ \\
\hline 8 & Gulshan & $6.9 \pm 0.28$ & $0.14 \pm 0.03$ & $105 \pm 9.25$ & $7.8 \pm 0.09$ & $69 \pm 0.14$ \\
\hline 9 & Shah Faisal & $7.2 \pm 0.20$ & $0.05 \pm 0.01$ & $101 \pm 6.25$ & $7.5 \pm 0.08$ & $49 \pm 0.10$ \\
\hline 10 & Landhi & $6.9 \pm 0.11$ & $0.16 \pm 0.04$ & $159 \pm 3.02$ & $7.3 \pm 0.21$ & $72 \pm 0.18$ \\
\hline 11 & Korangi & $7.9 \pm 0.24$ & $0.21 \pm 0.03$ & $152 \pm 2.05$ & $6.9 \pm 0.71$ & $63 \pm 1.32$ \\
\hline 12 & North Nazimabad & $6.7 \pm 0.09$ & $0.05 \pm 0.01$ & $32.0 \pm 2.03$ & $6.8 \pm 0.22$ & $32 \pm 0.19$ \\
\hline 13 & New Karachi & $6.5 \pm 0.18$ & $0.02 \pm 0.02$ & $67.0 \pm 8.52$ & $7.3 \pm 0.25$ & $63 \pm 0.17$ \\
\hline 14 & Gulberg & $7.6 \pm 0.19$ & $0.11 \pm 0.01$ & $96.0 \pm 5.20$ & $7.9 \pm 0.21$ & $49 \pm 3.59$ \\
\hline 15 & Liaquatabad & $7.2 \pm 0.09$ & $0.07 \pm 0.03$ & $79.3 \pm 5.02$ & $8.2 \pm 0.18$ & $58 \pm 2.30$ \\
\hline 16 & Malir & $6.5 \pm 0.15$ & $0.08 \pm 0.04$ & $75.3 \pm 3.02$ & $7.1 \pm 0.95$ & $49 \pm 2.36$ \\
\hline 17 & Binqasim & $6.2 \pm 0.02$ & $0.05 \pm 0.01$ & $59.0 \pm 2.01$ & $6.3 \pm 0.08$ & $23 \pm 5.23$ \\
\hline \multirow[t]{2}{*}{18} & Gadap & $7.0 \pm 0.01$ & $0.04 \pm 0.02$ & $99.0 \pm 6.30$ & $7.8 \pm 0.02$ & $71 \pm 1.29$ \\
\hline & WHO Standard & $6.5-8.5$ & No limit listed & 500 & No limit listed & $0-75$ \\
\hline
\end{tabular}

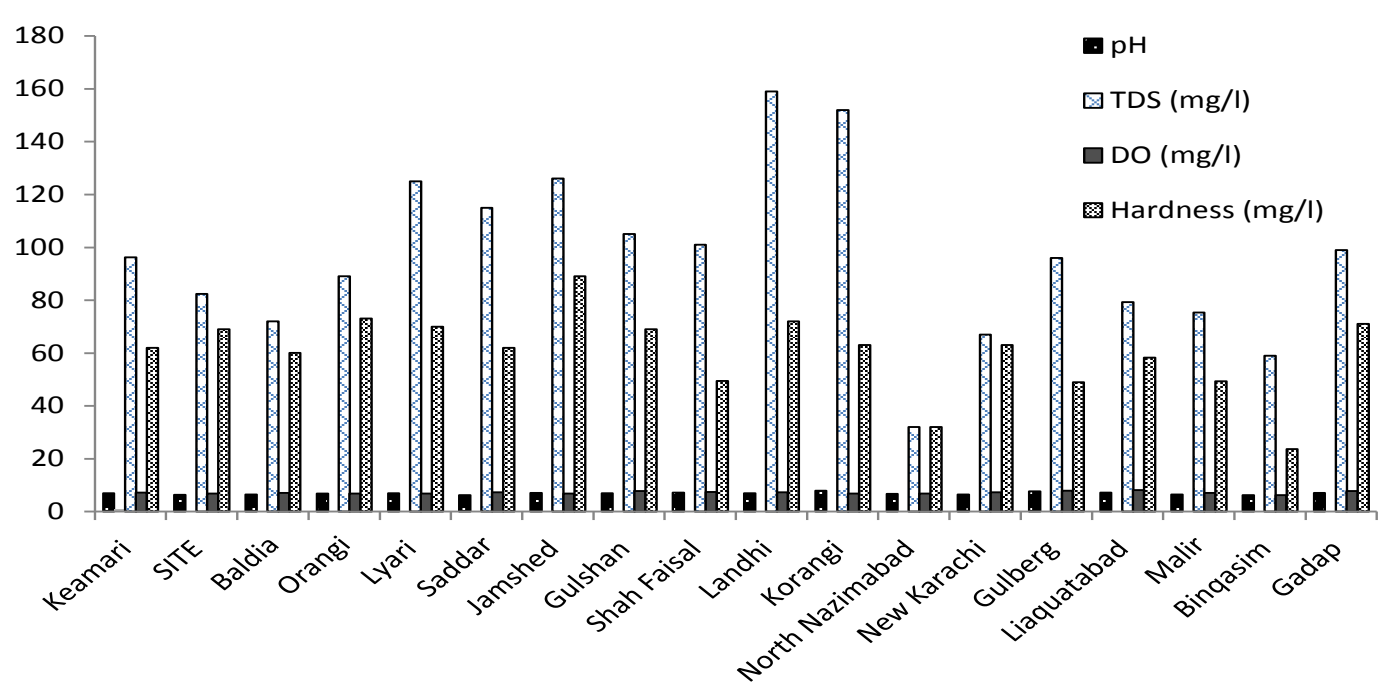

Figure 2. The physical parameters of rainwater at several places in Karachi, Pakistan.

\subsubsection{Conductivity}

The electrical conductivity is referred as key factor for determining the purity of water that depends on nature and concentration of ionized substances (chloride, nitrate, sulphate, and phosphate anions or sodium, magnesium, calcium, iron, and aluminium cations) in the water at water temperature. The conductivity in Karachi rainwater samples ranged between $0.02-0.21 \mathrm{~m} \cdot \mathrm{S} / \mathrm{cm}$. The minimum conductivity value was found in New Karachi where as maximum value is found in Korangi sample.

It is clear from the value of electrical conductivity of the samples that the rainwater of Karachi is free from considerable contamination of cations and anions from the atmosphere and it is pure water. Pure water also undergoes dissociation in which, $\mathrm{H}_{3} \mathrm{O}^{+}, \mathrm{OH}^{-}$ions presents in small quantity that shows little conductivity. The 
Table 2. Chemical composition of rainwater samples at different sites of Karachi in $\mathrm{mg} / \mathrm{l} \pm$ standard deviation.

\begin{tabular}{|c|c|c|c|c|c|c|c|c|c|}
\hline $\begin{array}{l}\text { S. } \\
\text { No. }\end{array}$ & $\begin{array}{l}\text { Parameters/ } \\
\text { Sampling } \\
\text { Sites }\end{array}$ & $\mathrm{NH}_{4}^{+}$ & $\mathrm{Na}^{+}$ & $\mathrm{K}^{+}$ & $\mathrm{Mg}^{2+}$ & $\mathrm{Ca}^{2+}$ & $\mathrm{NO}_{3}^{-}$ & $\mathrm{CO}_{3}^{2-}$ & $\mathrm{SO}_{4}^{2-}$ \\
\hline 1 & Keamari & $32.39 \pm 0.02$ & $125.45 \pm 0.12$ & $12.98 \pm 0.02$ & $240.39 \pm 0.11$ & $106.3 \pm 0.02$ & $89.60 \pm 0.0278 .69 \pm 0.09$ & $62.55 \pm 0.05$ & $3.32 \pm 0.15$ \\
\hline 2 & SITE & $59.88 \pm 0.05$ & $192.53 \pm 0.03$ & $6.99 \pm 0.13$ & $30.22 \pm 0.08$ & $31.39 \pm 0.04$ & $96.11 \pm 0.0345 .32 \pm 0.09$ & $49.58 \pm 0.06$ & $22.39 \pm 0.03$ \\
\hline 3 & Baldia & $64.02 \pm 0.01$ & $95.38 \pm 0.02$ & $5.02 \pm 0.02$ & $29.44 \pm 0.03$ & $35.89 \pm 0.04$ & $82.39 \pm 0.0331 .33 \pm 0.01$ & $39.33 \pm 0.02$ & $1.32 \pm 0.02$ \\
\hline 4 & Orangi & $36.66 \pm 0.05$ & $58.21 \pm 0.09$ & $6.35 \pm 0.07$ & $25.34 \pm 0.05$ & $28.99 \pm 0.04$ & $85.39 \pm 0.0833 .22$ & $40.39 \pm 0.07$ & $29.62 \pm 0.11$ \\
\hline 5 & Lyari & $59.39 \pm 0.02$ & $126.31 \pm 0.05$ & $6.91 \pm 0.08$ & $69.58 \pm 0.05$ & $106.23 \pm 0.05$ & $5139.0 \pm 0.0249 .58 \pm 0.03$ & $62.31 \pm 0.08$ & $42.77 \pm 0.05$ \\
\hline 6 & Saddar & $65.99 \pm 0.06$ & $136.32 \pm 0.13$ & $7.35 \pm 0.09$ & $42.33 \pm 0.05$ & $119.5 \pm 0.09$ & $133.3 \pm 0.1183 .03 \pm 0.12$ & $58.69 \pm 0.08$ & $72.36 \pm 0.09$ \\
\hline 7 & Jamshed & $78.9 \pm 0.08$ & $30.55 \pm 0.11$ & $7.20 \pm 0.05$ & $33.33 \pm 0.02$ & $58.93 \pm 0.11$ & $33.53 \pm 0.0533 .98 \pm 0.04$ & $50.11 \pm 0.09$ & $23.55 \pm 0.03$ \\
\hline 8 & Gulshan & $125.07 \pm 0.07$ & $49.37 \pm 0.09$ & $6.99 \pm 0.01$ & $59.35 \pm 0.05$ & $91.11 \pm 0.04$ & $41.21 \pm 0.0949 .88 \pm 0.05$ & $58.77 \pm 0.0$ & $39.33 \pm 0.11$ \\
\hline 9 & Shah Faisal & $45.32 \pm 0.08$ & $39.88 \pm 0.07$ & $6.58 \pm 0.11$ & $87.54 \pm 0.08$ & $75.41 \pm 0.07$ & $25.32 \pm 0.1213 .72 \pm 0.08$ & $22.01 \pm$ & $59.82 \pm 0.03$ \\
\hline 10 & Landhi & $135.52 \pm 0.03$ & $73.39 \pm 0.08$ & $8.97 \pm 0.05$ & $58.11 \pm 0.04$ & $97.71 \pm 0.09$ & $29.01 \pm 0.0521 .11 \pm 0.04$ & $44.44 \pm 0.03$ & $72.59 \pm 0.03$ \\
\hline 11 & Korangi & $56.33 \pm 0.09$ & $33.05 \pm 0.08$ & $5.39 \pm 0.08$ & $25.22 \pm 0.11$ & $42.36 \pm 0.13$ & $149.0 \pm 0.1583 .99 \pm 0.09$ & $54.60 \pm 0.05$ & $8.36 \pm 0.12$ \\
\hline 12 & $\begin{array}{c}\text { North } \\
\text { Nazimabad }\end{array}$ & $79.11 \pm 0.15$ & $86.21 \pm 0.13$ & $7.39 \pm 0.03$ & $28.72 \pm 0.11$ & $39.39 \pm 0.09$ & $61.01 \pm 0.1254 .19 \pm 0$ & $5.32 \pm 0$ & $.22 \pm 0.02$ \\
\hline 13 & New Karachi & $198.52 \pm 0.04$ & $102.22 \pm 0.09$ & $8.99 \pm 0.11$ & $39.52 \pm 0.09$ & $49.30 \pm 0.11$ & $49.99 \pm 0.0932 .44 \pm 0.09$ & $73.05 \pm 0$ & $9.65 \pm 0.03$ \\
\hline 14 & Gulberg & $72.39 \pm 0.09$ & $98.68 \pm 0.05$ & $9.87 \pm 0.13$ & $35.89 \pm 0.11$ & $63.33 \pm 0.13$ & $52.47 \pm 0.0345 .08 \pm 0.11$ & $42.36 \pm 0$ & $58.39 \pm 0.12$ \\
\hline 15 & Liaquatabad & $49.18 \pm 0.14$ & $32.58 \pm 0.11$ & $5.36 \pm 0.12$ & $29.33 \pm 0.13$ & $28.92 \pm 0.08$ & $47.23 \pm 0.0922 .93 \pm 0.13$ & $62.32 \pm 0.15$ & $21.44 \pm 0.01$ \\
\hline 16 & Malir & $59.66 \pm 0.02$ & $20.37 \pm 0.01$ & $4.37 \pm 0.03$ & $72.08 \pm 0.11$ & $62.82 \pm 0.07$ & $36.76 \pm 0.0532 .65 \pm 0.03$ & $28.35 \pm 0.08$ & $20.45 \pm 0.05$ \\
\hline 17 & Binqasim & $68.01 \pm 0.09$ & $32.90 \pm 0.08$ & $5.89 \pm 0.09$ & $32.58 \pm 0.02$ & $39.56 \pm 0.05$ & $31.25 \pm 0.0828 .32 \pm 0.12$ & $19.85 \pm 0.11$ & $52.69 \pm 0.09$ \\
\hline 18 & Gadap & $98.32 \pm 0.03$ & $68.78 \pm 0.12$ & $5.12 \pm 0.11$ & $54.82 \pm 0.09$ & $71.09 \pm 0.06$ & $35.33 \pm 0.0529 .38 \pm 0.04$ & $59.38 \pm 0.09$ & $32.45 \pm 0.06$ \\
\hline & HO Standard & No limit listed & 200 & $\begin{array}{l}\text { No limit } \\
\text { listed }\end{array}$ & 50 & 200 & 250 & $\begin{array}{c}\text { No limit } \\
\text { listed }\end{array}$ & 250 \\
\hline
\end{tabular}

conductivity values obtained from rainwater analysis meets the WHO (World Health Organization) guideline values of conductivity of safe drinking water [23].

\subsubsection{Total Dissolved Solids}

Total dissolved solids (TDS) are the solids present in water in the dissolved form. TDS is very significant parameter describing the chemical constituents of the water and can be considered as general of edaphically relation that contributes to productivity within the water body [24]. Sulphurous and carbonic acids are present in rainwater but they have no effect on its hardness. It is clear from the TDS of rainwater that more is the TDS value more will be the suspended and dust particles in it. TDS of rainwater also depends upon quantity of rain fall. The TDS values also show that the rainwater can be described as fresh. Based on the Australian and UNESCO standard for livestock which stated that the TDS values between 0 to $2900 \mathrm{mg} / \mathrm{l}$ are suitable for all animals [25]. The values obtained in rainwater samples indicate that it is suitable for livestock farming since the TDS ranged from 32 to 159 mg/l. The minimum concentration found in North Nazimabad where as maximum concentration was found in Landhi sample.

\subsubsection{Dissolved Oxygen}

Assessment of dissolved oxygen (DO) is a major characteristic in all pollution related ecological studies [26]. The value of dissolved oxygen in samples ranged from $6.3-8.2 \mathrm{mg} / \mathrm{l}$. The lowest value was observed in Binqasim sample and the highest value was observed in Liaquatabad sample.

\subsubsection{Hardness}

The total hardness of the rainwater varied from 23 to $89 \mathrm{mg} / \mathrm{l}$. The lowest value is found in Binqasim rainwater sample while the highest value is found in Jamshed town sample. In only one sample hardness exceed the WHO (World Health Organization) standard value [23]. The low concentration of hardness is due to low concentration of calcium and magnesium ions in the rainwater. Hence, it can be said that rainwater is not hard and it can be used for washing purpose. 


\subsection{Major Cations and Anions}

Rainwater is a mixed electrolyte that contains varying amounts of major and minor ions. Sodium, potassium, magnesium, calcium, chloride, bicarbonate, and sulphate ions are major constituents, together with ammonia, nitrate, nitrite and other nitrogenous compounds.

There is a considerable range in the amounts of the ions present in rainwater of Karachi (Figures 3 and 4).

The main source of dissolved materials such as $\mathrm{Na}^{+}$and $\mathrm{Cl}^{-}$, in the rainwater is sea salt. When waves split, fine droplets of seawater are injected into the atmosphere. The water evaporates, leaving a solid aerosol particle, which is transported by winds until it is dissolved by rain. This process is responsible for the high concentrations of $\mathrm{Na}^{+}$and $\mathrm{Cl}^{-}$in rainwater. The concentrations of $\mathrm{Na}^{+}$ranged in between 20.37 to $192.53 \mathrm{mg} / \mathrm{l}$ and $\mathrm{Cl}^{-}$concentrations ranged from 25.32 to $149.0 \mathrm{mg} / \mathrm{l} . \mathrm{Ca}^{2+}, \mathrm{Mg}^{2+}$ and $\mathrm{K}^{+}$ions in rainwater are presumably come both from oceanic salts and dust in the atmosphere from land surface. The concentrations of $\mathrm{Ca}^{2+}$ varied from 28.92 to $119.58 \mathrm{mg} / \mathrm{l}$; while that of $\mathrm{Mg}^{2+}$ and $\mathrm{K}^{+}$varied from 25.22 to $87.54 \mathrm{mg} / \mathrm{l}$ and 4.37 to $12.98 \mathrm{mg} / \mathrm{l}$, respectively.

The concentration of $\mathrm{Mg}^{2+}$ in Lyari, Gulshan, Shah Faisal, Landhi, Malir and Gadap samples is comparatively higher from the WHO standard values of fresh water i.e. $50 \mathrm{mg} / \mathrm{l}$. $\mathrm{NO}_{3}^{-}$is derived from plants, agriculture animal waste and fertilizers, and automobile exhausts. It is one of the major nitrogenous contributions to the chemical composition of precipitation. The $\mathrm{HNO}_{3}$ (gaseous) which results from the oxidation of $\mathrm{NO}_{\mathrm{x}}$ is water soluble, meaning it is washed away by precipitation, constituting one of the most important sources of $\mathrm{NO}_{3}^{-}$in rainwater [27]. In the case of nitrate, it is important to consider the variations in the efficiency of conversion from $\mathrm{NO}_{2}$ to gaseous $\mathrm{HNO}_{3}$. In summer, this conversion occurs rapidly, while in the winter it is slower [28] [29]. The concentration of nitrate in rainwater samples of Karachi is ranged between 13.72 - $83.99 \mathrm{mg} / \mathrm{l}$. Minimum concentration was found in Shah Faisal colony sample while maximum concentration was found in Korangisample. The rainwater of North Nazimabad, Korangi, Gulshan, Saddar, Lyari, SITE and Keameri are more ex-

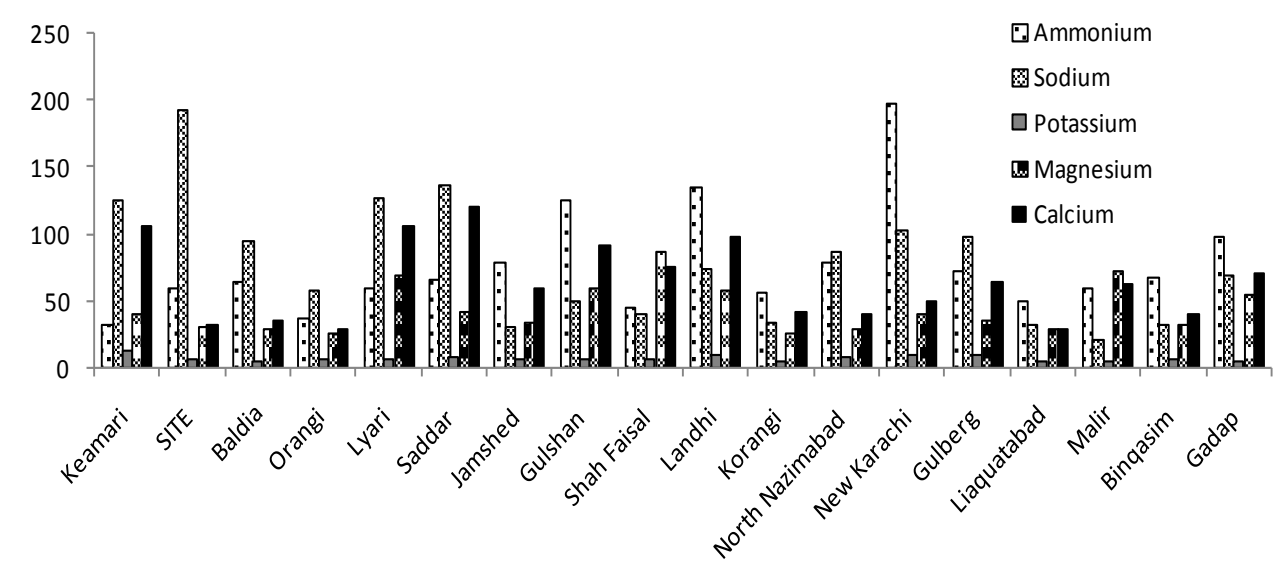

Figure 3. The concentration of cations in rainwater at several places in Karachi, Pakistan.

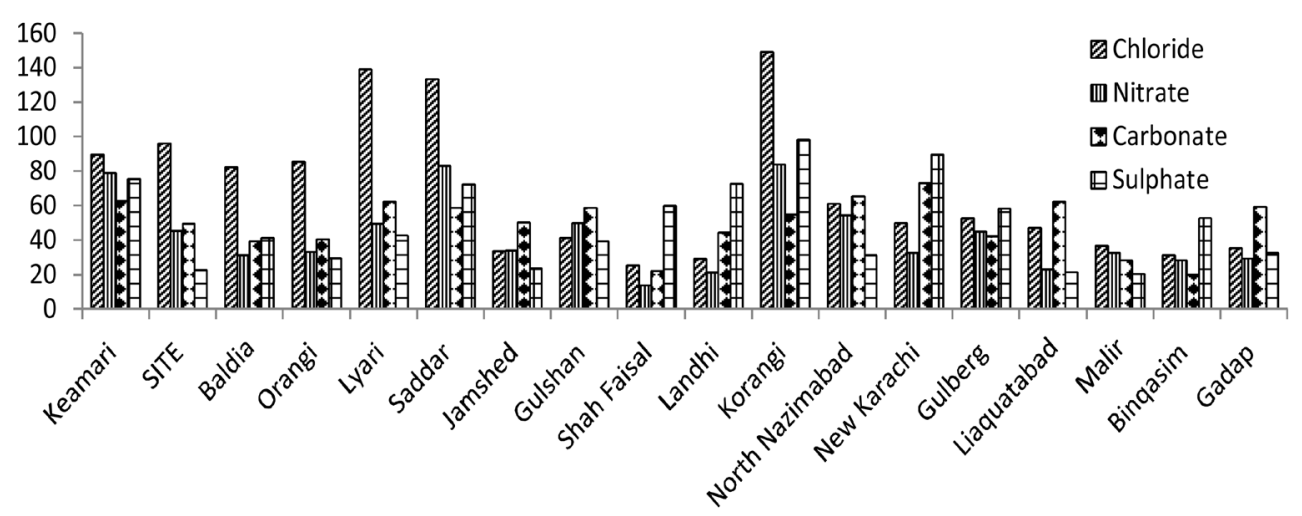

Figure 4. The concentration of anions in rainwater at several places in Karachi, Pakistan. 
posed to automobile exhaust and they are found contaminated with more $\mathrm{NO}_{3}^{-}$as compare to other areas samples.

The second contribution to nitrogenous rainwater composition is of ammonium. Its presence in precipitations results in the condensation of aerosols containing ammonium and of the incorporation of gaseous ammonia in cloud droplets. Major sources of ammonia are known to be natural or fertilized soils, excrements of human and animals, and wood burnings. Also, in the atmosphere ammonium that mainly associated with farming and biomass burning mainly combines with sulphate and nitrate to form ammonium sulphate and ammonium nitrate, respectively [30]-[32]. The concentrations of $\mathrm{NH}_{4}^{+}$ranged from 32.39 to $198.52 \mathrm{mg} / \mathrm{l}$. The minimum concentration of ammonium is found in Keamari rainwater sample i.e. $32.39 \mathrm{mg} / \mathrm{l}$ where as maximum concentration of ammonium is found in New Karachi samples i.e. $198.52 \mathrm{mg} / \mathrm{l}$.

$\mathrm{SO}_{4}^{2-}$ is formed by $\mathrm{SO}_{2}$ gas emission from automobile exhaust. It reacts with water droplets and accounts for the source of sulphate ions in rainwater. In collected samples the $\mathrm{SO}_{4}^{2-}$ ranged from 20.45 to $98.36 \mathrm{mg} / \mathrm{l}$. The highest concentration is found in Korangi and lowest concentration is found in Malir. $\mathrm{CO}_{3}^{2-}$ and $\mathrm{HCO}_{3}^{-}$in rainwater is formed by the dissociation of carbonic acid formed by the reaction of carbon dioxide gas with water [33]. The concentrations of $\mathrm{CO}_{3}^{2-}$ in Karachi rainwater varied from lowest value of $19.85 \mathrm{mg} / \mathrm{l}$ in Binqasim to highest value of $73.05 \mathrm{mg} / \mathrm{l}$ in New Karachi samples.

In general, the results indicate that the concentrations of the constituent major cations and anions are low and this is typical for most rainwater resources in industrialized urban areas [34]. Moreover, the concentration of major cations and anions of the rainwater conform to the standard for safe drinking water.

\section{Conclusions}

The chemical contents of rainwater form a useful parameter to disclose the characteristics of rain in question. Therefore, it is concluded from the analysis that the rainwater of Karachi city is not polluted significantly.

Although, further studies are needed in order to complete this data with aspects such as organic deposition or dry deposition in order to create a complete database that permits evaluating modelling exercises and improving knowledge about future environmental and human health impacts.

\section{Acknowledgements}

The authors are extremely thankful to PCSIR Laboratories Complex Karachi-75280, Pakistan for providing instrumental facilities for the analysis of rainwater samples .

\section{References}

[1] Mouli, P.C., Mohan, S.V. and Reddy, S.J. (2005) Rainwater Chemistry at a Regional Representative Urban Site: Influence of Terrestrial Sources on Ionic Composition. Atmospheric Environment, 39, 999-1008. http://dx.doi.org/10.1016/j.atmosenv.2004.10.036

[2] Fargeli, H. and Aas, W. (2008) Trends of Nitrogen in Air and Precipitation: Model Results and Observations at EMEP Sites in Europe, 1980-2003. Environmental Pollution, 154, 448-461. http://dx.doi.org/10.1016/j.envpol.2008.01.024

[3] Shen, Z., Wang, X., Zhang, R., Ho, K., Cao, J. and Zhang, M. (2011) Chemical Composition of Water Soluble Ions and Carbonate Estimation in Spring Aerosol at a Semi-Arid Site of Tongyu, China. Aerosol and Air Quality Research, 10, 360-368.

[4] Boubel, R.W., Fox, D.L., Turner, D.B. and Stern, A.C. (1994) Fundamentals of Air Pollution. 3rd Edition, Academic Press, Inc., San Diego, 149-152.

[5] Elsom, D. (1987) Atmospheric Pollution: Causes, Effects and Control Policies. Blackwell, Basil.

[6] Al-Momani, F., Gullu, G., Olmez, I., Eler, U., Ortel, E., Sirin, G. and Tuncel, G. (1997) Chemical Composition of Eastern Mediterranean Aerosol and Precipitation: Indications of Long Range Transport. Pure and Applied Chemistry, 69, 41-46. http://dx.doi.org/10.1351/pac199769010041

[7] Granat, L., Suksomsankh, K., Simachaya, S., Tabucanon, M. and Rodhe, H. (1996) Regional Background Acidity and Chemical Composition of Precipitation in Thailand. Atmospheric Environment, 30, 1589-1596. http://dx.doi.org/10.1016/1352-2310(95)00455-6

[8] Possanzini, M., Buttini, P. and Di Palo, V. (1988) Characterization of a Rural Area in Terms of Dry and Wet Deposition. Science of the Total Environment, 74, 111-120. http://dx.doi.org/10.1016/0048-9697(88)90132-5

[9] Kulshrestha, U.C., Kulshrestha, M.J., Sekar, R., Variamani, M., Sarkar, A.K. and Parashar, D.C. (2001) Investigation 
of Alkaline Nature of Water in India. Water, Air, and Soil Pollution, 130, 1685-1690.

[10] Kelly, T.J., McLaren, S.E. and Kadlecek, J.A. (1989) Seasonal Variations in Atmospheric $\mathrm{SO}_{\mathrm{x}}$ and $\mathrm{NO}_{\mathrm{x}}$ Species in the Adirondacks. Atmospheric Environment, 23, 1315-1332. http://dx.doi.org/10.1016/0004-6981(89)90155-8

[11] Bard, S.M. (1999) Global Transport of Anthropogenic Contaminants and the Consequences for the Arctic Marine Ecosystem. Marine Pollution Bulletin, 38, 356-379. http://dx.doi.org/10.1016/S0025-326X(99)00041-7

[12] Bierwagen, G., Shedlosky, T.R. and Stanek, K. (2003) Developing and Testing a New Generation of Protective Coatings for Outdoor Bronze Sculpture. Progress in Organic Coatings, 48, 289-296. http://dx.doi.org/10.1016/j.porgcoat.2003.07.004

[13] Samara, C., Tsitouridou, R. and Balafotis, C.H. (1992) Chemical Composition of Rain in Thessaloniki, Greece, in Relation to Meteorological Conditions. Atmospheric Environment, 26B, 359-367. http://dx.doi.org/10.1016/0957-1272(92)90011-G

[14] Smirnioudi, V.N. and Siskos, P.A. (1992) Chemical Composition of Wet and Dust Deposition in Athens, Greece. Atmospheric Environment, 26B, 483-490. http://dx.doi.org/10.1016/0957-1272(92)90055-W

[15] Raper, D.W. and Lee, D.S. (1996) Wet Deposition at the Sub-20km Scale in a Rural Upland Area of England. Atmospheric Environment, 30, 1193-1207. http://dx.doi.org/10.1016/1352-2310(95)00459-9

[16] Sanusi, A., Wortham, H., Millet, M. and Mirabel, P. (1996) Chemical Composition of Rainwater in Eastern France. Atmospheric Environment, 30, 59-71. http://dx.doi.org/10.1016/1352-2310(95)00237-S

[17] Datar, S.V., Mukhopadhyay, B. and Srivastava, H.N. (1996) Trends in Background Air Pollution Parameter over India. Atmospheric Environment, 30, 3677-3682. http://dx.doi.org/10.1016/1352-2310(96)00052-0

[18] Hasan, A. and Mohib, M. (2003) Urban Slums Reports: The Case of Karachi, Pakistan.

[19] Chughtai, M., Mustafa, S., Mahmood, R. and Mumtaz, M. (2014) Physicochemical Assessment of Rainwater of Karachi, Pakistan. European Academic Research, 1, 4099-4108.

[20] Rao, P.S.P., Momin, G.A., Safai, P.D., Pillai, A.G. and Khemani, L.T. (1995) Rainwater and Throughfall Chemistry in the Silent Valley Forest in South India. Atmospheric Environment, 29, 2025-2029. http://dx.doi.org/10.1016/1352-2310(94)00294-U

[21] Tu, J., Wang, H.S., Zhang, Z.F., Jin, X. and Li, W.Q. (2005) Trends in Chemical Composition of Precipitation in Nanjing, China, during 1992-2003. Atmospheric Research, 73, 283-298. http://dx.doi.org/10.1016/j.atmosres.2004.11.002

[22] Zhang, M.Y., Wang, S.J., Wu, F.C., Yuan, X.H. and Zhang, Y. (2007) Chemical Compositions of Wet Precipitation and Anthropogenic Influences at a Developing Urban Site in South Eastern China. Atmospheric Research, 84, 311-322. http://dx.doi.org/10.1016/j.atmosres.2006.09.003

[23] World Health Organization (2006) Guidelines for Drinking Water Quality. Vol. 1, Recommendations, Geneva.

[24] Goher, M.E.M. (2002) Chemical Studies on the Precipitation and Dissolution of Some Chemical Element in Lake Qarun. Ph.D. Thesis, Al-Azhar University, Egypt.

[25] Hamhill, L. and Bell, F.G. (1986) Groundwater Resources Development. University Press, Cambridge, 344.

[26] Vijayan, V.S. (1991) Keoladeo National Park Ecology Study. Final Report (1980-1990) BNHS, Bombay.

[27] Kumar, S. (1986) Reactive Scavenging of Pollutants by Rain: A Modelling Approach. Atmospheric Environment, 20, 1015-1024. http://dx.doi.org/10.1016/0004-6981(86)90287-8

[28] Van Egmond, N.D. and Kesseboom, H. (1985) A Numerical Mesoscale Model for Long Term Average $\mathrm{NO}_{\mathrm{x}}$ and $\mathrm{NO}_{2}{ }^{-}$ Concentration. Atmospheric Environment, 19, 587-595. http://dx.doi.org/10.1016/0004-6981(85)90037-X

[29] Ruijgrok, W., Visser, H. and Romer, F.G. (1992) The Scavenging and Wet Deposition of Acidifying Components in Arnhem: 1984-1990. In: Schwartz, S.E. and Slinn, W.G.N., Eds., Precipitation Scavenging and Air-Surface Exchange, Hemisphere Publishing Corp., Washington DC, 471-482.

[30] Meng, Z. and Seinfeld, J.H. (1994) On the Source of the Submicrometer Droplet Mode of Urban and Regional Aerosols. Aerosol Science and Technology, 20, 253-265. http://dx.doi.org/10.1080/02786829408959681

[31] Redington, A.L. and Derwent, R.G. (2002) Calculation of Sulphate and Nitrate Aerosol Concentrations over Europe Using a Lagrangian Dispersion Model. Atmospheric Environment, 36, 425-439. http://dx.doi.org/10.1016/S1352-2310(02)00420-X

[32] Pathak, R.K., Wu, W.S. and Wang, T. (2009) Summer Time $\mathrm{PM}_{2.5}$ Ionic Species in Four Major Cities of China: Nitrate Formation in an Ammonia Deficient Atmosphere. Atmospheric Chemistry and Physics, 9, 1711-1722. http://dx.doi.org/10.5194/acp-9-1711-2009

[33] Drever, J.I. (1997) The Geochemistry of Natural Waters. 3rd Edition, Prentice Hall, 436.

[34] Back, W. and Hanshaw, B. (1965) Chemical Geohydrology Advances in Hydroscience. Academic Press, New York, 49-109. 